\title{
KUALITAS PELAYANAN UPTD PUSKESMAS PERAWATAN BARU ULU DI KOTA BALIKPAPAN PADA TAHUN 2020
}

\author{
${ }^{1}$ Endik Hidayat, 2 Lidya Britania Putong, ${ }^{3}$ Maria Veronika Andarista ${ }^{4}$ Hidayati Syan Yumna \\ 1,2,3,4 Program Studi Administrasi Publik Fakultas IImu Sosial dan IImu Politik \\ Universitas Pembangunan Nasional "Veteran" Jawa Timur \\ Email : endik.hidayat.adneg@upnjatim.ac.id, britanialbp@gmail.com \\ Surabaya, 60294, Indonesia
}

\begin{abstract}
Health is one of the most important needs for every individual. The society can't carry out their own self-care without health worker services. Therefore, health service is one of the things that must be obtained by the society from the government, this corresponds to Undang - Undang Dasar 1945 Pasal 34 ayat (3) which states that the state is responsible for the provision of adequate health service facilities and public service facilities. UPTD Puskesmas Perawatan Baru Ulu has a function to provide services to the community in Baru Ulu urban Village. Based on the survey, the community satisfaction index conducted by the Balikpapan City government on the quality of service at the UPTD Puskesmas Perawatan Baru Ulu in 2020 has decreased compared to the previous year. The purpose of this study is to know how the service quality in UPTD Puskesmas Perawatan Baru Ulu. This research uses the theory of public service quality and uses a qualitative descriptive method by conducting interviews. The results of this study indicate that the quality of service at UPTD Puskesmas Perawatan Baru Ulu in 2020 is good. However, there needs to be improvements in several things such as the punctuality of doctors' arrival and employee ethics.
\end{abstract}

Keywords: Publik Service; Puskesmas; Service Quality

\begin{abstract}
Abstrak
Kesehatan merupakan salah satu kebutuhan terpenting bagi setiap individu. Masyarakat tidak bisa melakukan perawatan sendiri tanpa pelayanan tenaga kesehatan. Oleh karena itu, pelayanan Kesehatan merupakan salah satu hal yang wajib didapatkan oleh masyarakat dari pemerintah, hal ini sesuai dengan Undang-undang Dasar 1945 Pasal 34 ayat (3) yang menyatakan negara bertanggungjawab atas penyediaan fasilitas pelayanan kesehatan dan fasilitas pelayanan umum yang layak. UPTD Puskesmas Perawatan Baru Ulu memiliki fungsi untuk memberikan pelayanan kepada masyarakat di Kelurahan Baru Ulu. Berdasarkan survey indeks kepuasan masyarakat yang dilakukan oleh pemerintah Kota Balikpapan terhadap kualitas pelayanan di UPTD Puskesmas Perawatan Baru Ulu pada tahun 2020 mengalami penurunan dibandingkan dengan tahun sebelumnya. Penelitian ini bertujuan untuk mengetahui bagaimana kualitas pelayanan di UPTD Puskesmas Perawatan Baru Ulu Kota Balikpapan pada tahun 2020. Penelitian ini menggunakan teori kualitas pelayanan publik dan menggunakan metode deskriptif kualitatif dengan melakukan wawancara. Hasil penelitian ini menunjukkan bahwa kualitas pelayanan di UPTD Puskesmas Perawatan Baru Ulu KotaBalikpapan pada tahun 2020 sudah baik. Namun, perlu ada perbaikan dalam beberapa hal seperti ketepatan waktu kedatangan dokter dan etika pegawai.
\end{abstract}

Kata Kunci: Kualitas Pelayanan; Puskesmas; Pelayanan Publik

Open Access at:http://ojs.uho.ac.id/index.php/PUBLICUHO/index

Journal Publicuho is licensed under a Creative Commons Attribution 4.0 International License. 


\section{Journal Publicuho}

ISSN2621-1351 (online), ISSN 2685-0729 (print)

Volume 4 Number 2 (May-July), (2021)pp. 612-626

Accredited SINTA SK.NOMOR 28/E/KPT/2019

Open Access at:http://ojs.uho.ac.id/index.php/PUBLICUHO/index

DOI: 10.35817/jpu.v4i2.18117

\section{PENDAHULUAN}

Kebutuhan dasar yang terpenting dalam kehidupan manusia adalah kesehatan. Manusia yang memiliki kebugaran jasmani dapat beraktivitas dengan bebas oleh karena itu kesehatan menjadi bagian terpenting dalam kesejahteraan warga negara. Masyarakat menyandang hak yang serupa akan memperoleh pelayanan kesehatan yang terbaik (Khozin \& Mutmainah, 2019). Kesehatan adalah kekayaan, begitu pula penyampaian layanan yang cepat dan berkualitas penting bagi keberadaan manusia (Kuye \& Akinwale, 2020). Pelayanan dalam bidang kesehatan diharuskan bisa meningkatkan kualitas pelayanan dan independen dalam memberikan jasa yang berkualitas sehingga masyarakat dapat degan mudah memanfaatkan jasa pelayanan kesehatan. (Lukman Arif, 2019). Menurut Sinambela (2010) dalam (Khozin \& Mutmainah, 2019) mengemukakan pada hakikatnya manusia memerlukan pelayanan, karena pelayanan sangat tidak mungkin terpisah dari kehidupan manusia. Untuk meningkatkan kesehatan masyarakat, diperlukan partisipasi dari berbagai organisasi dan lembaga sosial (Valadi-khorram et al., 2020). Berdasarkan Undang-Undang Republik Indonesia Nomor 25 Tahun 2009 memaklumatkan bahwa negara bertanggungjawab dalam melayani setiap warga negara dalam memenuhi hak serta kebutuhan mendasar dalam melaksanakan pelayanan publik (Krismanto \& Irianto, 2020). Cakupan pelayanan publik mencakup pelayanan barang public dan jasa publik termasuk pelayanan administratif yang terdapat dalam peraturan perundang-undangan bidang Kesehatan.

Pelayanan kesehatan patut dilaksanakan oleh pemerintah, perihal tersebut tercantum dalam Undang-Undang Dasar Tahun 1945 pasal 28 H ayat (1) yang menyatakan bahwa seluruh masyarakat memiliki hak hidup sentosa, memiliki tempat tinggal, dan mendapatkan lingkungan hidup yang berkualitas serta berhak atas pelayanan Kesehatan sedangkan dalam Pasal 34 ayat 3 memaklumatkan bahwa negara bertanggungjawab akan pengadaan akomodasi pelayanan kesehatan serta akomodasi pelayanan standar yang berkualitas. Menurut Azwar (2010) dalam artikel (Shobirin, 2016) pelayanan kesehatan ialah segala ikhtiar yang dikelola ala seorangan maupun kelompok yang terdapat di dalam sebuah organisasi demi mengupayakan dan memajukan Kesehatan, menghindari dan memulihkan Kesehatan perorangan ataupun kelompok dalam masyrakat. Suwardi (2011) dalam (Sunardi, 2017) berpendapat bahwa pada dasarnyan pelayanan sama pentingnya dengan menciptakan kepuasan, dalam hal ini kepuasan pengguna bergantung pada proses interaksi antara pemberi layanan dan pengguna layanan. (Azhar, 2018). Dalam menjalankan peraturan Undang - Undang tersebut pemerintah menyelenggarakan pelayanan kesehatan kepada masyarakat dengan membangun Pusat Kesehatan Masyarakat (Puskesmas) dalam setiap kecamatan sebagai Unit Pelaksana Teknis (UPT) Dinas 
Kesehatan kabupaten/kota (Umardiono et al., 2019). Berdasarkan Peraturan Menteri Kesehatan RI Nomor 75 Tahun 2014 tentang Pusat Kesehatan Masyarakat (Puskesmas) ialah prasarana servis Kesehatan yang melangsungkan usaha promotive dan pencegahan yang bertujuan menggapai taraf Kesehatan masyarakat yang setinggi-tingginya di wilayah kerja puskesmas. Untuk mencapai taraf tersebut denga usaha kesehatan berdasarkan Peraturan Menteri Kesehatan RI Nomor 75 Tahun 2014 tersebut maka berdasarkan perihal itu pelaku kesehatan diwajibkan mengupayakan seluruh kemampuannya dengan baik (Tarawiyah, 2017).

Puskesmas yaitu institusi yang menjalankan usaha kesehatan yang memiliki sifat komprehensif, terintegrasi, mudah diterima dan dijangkau untuk masyarakat melalui kedudukan yang aktif bersama-sama memanfaatkan hasil teknologi secara efisien atas anggaran yang mampu ditanggung oleh masyarakat serta pemerintah (Muis, 2017). Demi terciptanya pengembangan kesehatan ke arah Indonesia sehat, puskesmas menjalankan fungsi kebijakan kesehatan yang bertujuan untuk menumbuhkan kesadaran, ketersediaan dan kesanggupan untuk hidup sehat bagi masyarakat (Utami \& Nawangsari, 2016). Dalam melaksanakan tugasnya puskesmas diharapkan dapat cepat tanggap memberikan pelayanan kepada masyarakat yang sedang berobat. Kualitas dalam perawatan kesehatan selalu dikaitkan dengan kepuasan konsumen (Verma et al., 2020). Untuk mengukur kualitas pelayanan dapat menggunakan metode survey indeks kepuasan masyarakat (IKM). Indikator kepuasan masyarakat yaitu data dan informasi terkait derajat kepuasan masyarakat yang didapat dari hasil pengukuran secara kuantitatif maupun kualitatif berdasarkan pemikiran masyarakat dalam mendapatkan pelayanan dari apartur penyelenggara pelayanan publik dengan cara mengkomparasikan antara harapan dan kebutuhan (Daton, 2020). Kepuasan adalah keadaan yang dirasakan seseorang yang persyaratannya telah terpenuhi (Islam et al., 2011) dalam (Gajewska et al., 2019). Jani dan Han (2013) dalam (Rahman, 2019) mendalilkan bahwa jika konsumen mengevaluasi keseluruhan pengalaman konsumsi mereka dengan memuaskan, kemungkinan tingkat kepuasan mereka untuk membeli kembali akan meningkat.

Berdasarkan hasil survey indeks kepuasan masyarakat dari UPTD Puskesmas Perawatan Baru Ulu Balikpapan menunjukkan penurunan kepuasan dari tahun 2019 ke 2020. Data yang diperoleh adalah sebagai berikut:

Tabel 1. Indeks Kepuasan Masyarakat tahun 2019-2020

\begin{tabular}{ccc}
\hline PRODUK LAYANAN & Tahun 2019 & Tahun 2020 \\
\hline UPTD Puskesmas Perawatan Baru Ulu & 79.87 (A) & 76.28 (C) \\
\hline
\end{tabular}

Sumber : balikpapan.go.id

Eksistensi kaidah normal untuk memformulasikan indeks kepuasan masyarakat ialah komponen dari usaha untuk mewujudkan objektivitas pelayanan kepada masyarakat dalam 


\section{Journal Publicuho}

ISSN2621-1351 (online), ISSN 2685-0729 (print)

Volume 4 Number 2 (May-July), (2021)pp. 612-626

Accredited SINTA SK.NOMOR 28/E/KPT/2019

Open Access at:http://ojs.uho.ac.id/index.php/PUBLICUHO/index

DOI: 10.35817/jpu.v4i2.18117

rangka melaksanakan otonomi daerah. (Abdussamad, 2019). Penurunan kepuasan masyarakat ini juga sebagai tolak ukur bahwa kinerja puskesmas di Balikpapan juga mengalami penurunan. Oleh karena itu kami melakukan penelitian bagaimana kualitas pelayanan publik di Puskesmas Balikpapan di tahun 2020. Penaksiran derajat kualitas pelayanan dibutuhkan untuk memperoleh input perihal kekurangan layanan agar dapat dilaksanakan perbaikan layanan sesuai pengguna layanan (Hernikawati, 2018). Penelitian ini bertujuan untuk menganalisis kualitas layanan yang dilakukan oleh UPTD Puskesmas Perawatan Baru Ulu Balikpapan Hasilnya diharapkan dapat menjadi bahan evaluasi untuk membenahi dan memajukan pelayanan yang dirasa masih kurang maksimal. Hal tersebut sesuai dengan pernyataan (Shabbir et al., 2017) bahwa pemeriksaan kualitas layanan membantu manajer layanan untuk mengalokasikan sumber daya melalui sistem yang makin bagus sehingga dapat meningkatkan citra organisasi.

\section{KAJIAN PUSTAKA}

\section{Konsep Kualitas}

Kualitas pelayanan suatu institusi adalah indikator kesuksesan sistem pengelolaan organisasi di instansi institusi privat ataupun pemerintahan (Dewi Maharani, 2019). Goetsch dan Davis (dalam Ismail, 2019) mendefiniskan kualitas secara lebih luas yaitu : Kualitas merupakan sebuah kadaan hidup yang berasosiasi melalui produksi, servis, manusia, proses dan lingkungan yang menggenapi alias melebih impian (Pratama \& Widiyarta, 2016). Selain itu, kualitas ialah kelengkapan indentitas dan keunikan suatu produk maupun pelayanan yang berimbas atas kompetensinya untuk pemuas kepentingan yang terlihat maupun yang tak terlihat (Rezha, 2013). Kualitas pelayanan memerankan salah satu factor determinan dalam memelihara keberlangsungan organisasi public ataupun organisasi privat (Nawangsari et al., 2016).

Menurut Wyckof dan Lovelock (dalam Rosyadi, 2017) kualitas adalah tingkat keunggulan yang diharapkan dan pengendalian atas tingkat keunggulan tersebut untuk memenuhi keinginan pelanggan. Hospital service quality is usually defined in academic literature as "the discrepancy between patients and/or their attendants perception of service offered and their expectations about that hospital offering such services (Upadhyai et al., 2020). (Kualitas layanan rumah sakit biasanya didefinisikan dalam literatur akademis sebagai "perbedaan antara pasien dan / atau persepsi petugas mereka tentang layanan yang ditawarkan dan harapan mereka tentang rumah sakit yang menawarkan layanan tersebut"). Berdasarkan pengertian diatas dapat disimpulkan bahwa kualitas adalah standar pelayanan terbaik seseorang maupun lembaga kepada masyarakat yang berhubungan dengan produk, jasa, manusia proses dan juga lingkungan yang memenuhi atau melebihi harapan untuk memuaskan kebutuhan yang dinyatakan atau yang tersirat. 


\section{Konsep Jasa}

Kotler \& Keller (2012) (dalam Didin Fatihudin \& Anang Firmansyah, 2019) menurut mereka bahwa jasa merupakan setiap aktivitas, manfaat atau performance yang ditawarkan oleh satu pihak ke pihak lain yang bersifat intangible dan tidak menyebabkan perpindahan segala kepemilikan yang dalam produksinya dapat terkait maupun tidak dengan produk yang berupa wujud. Norman (2002) (dalam Didin Fatihudin \& Anang Firmansyah, 2019) jasa adalah kontak sosial yang termasuk tindakan dan interaksi, dan jasa adalah suatu interaksi sosial produsen dengan konsumen.

Dapat disimpulkan jasa merupakan segala bentuk korelasi antara pemberi jasa dengan pengguna jasa yang sifatnya intangible dan tidak menimbulkan berpindahnya suatu kepemilikan.

\section{Konsep Pelayanan Publik}

Pelayanan publik ditafsirkan sebagai pelayanan yang disampaikan kepada seseorang maupun orang yang berkeperluan dalam organisasi sesuai dengan aturan dan prosedur dasar yang ditentukan ( dalam John Fresly Hutahaen, A Yuli Andi Gani, Choirul Saleh, 2018). Dalam (Kamus Besar Bahasa Indonesia, 1990), pelayanan publik diinterpretasikan sebagai :

a) Pelayanan adalah mengenai suatu cara dalam konsep melayani.

b) Pelayanan adalah fasilitas yang diberikan yang termasuk interaksi dagang barang dan jasa.

c) Pelayanan medis adalah suatu bentuk pelayanan yang didapatkan oleh seseorang termasuk hubungannya dengan penghindaran, diagnosis dan mengobati suatu kendala dalam kesehatan.

d) Publik diartikan banyak (umum)

Pengertian lainnya menjelaskan bahwa pelayanan umum yaitu suatu upaya yang dilaksanakan oleh seseorang, kelompok maupun birokrasi untuk menyampaikan bantuan ataupun pertolongan kepada semua masyarakat dalam rangka mendapatkan suatu sasaran ataupun target tertentu (Risnawan, 2017). Menurut Rasyid (1997:116) dalam (Yusuf \& Banga, 2019) menegaskan bahwa pelayanan publik berkenaan dengan usaha pemerintah yang bermaksud untuk menciptakan kondisi yang menjamin bahwa semua masyarakat mampu menjalani kehidupannya secara wajar dan ditujukan juga untuk membangun dan memelihara keadilan dalam masyarakat.

Sehingga, dapat diambil kesimpulan bahwa pelayanan publik ialah semua bentuk jasa pelayanan yang diberikan kepada orang banyak baik berupa barang maupun jasa sesuai dengan aturan dan prosedur dasar yang telah ditetapkan.

Menurut Dwiyanto (2006:56) yang dikutip dari La Ode Muhammad Elwan. (2019) bahwa pemberian pelayanan publik oleh aparatur pemerintah kepada masyarakat (publik) merupakan perwujudan dan fungsi aparatur negara sebagai pelayan masyarakat (abdi), 


\section{Journal Publicuho}

ISSN2621-1351 (online), ISSN 2685-0729 (print)

Volume 4 Number 2 (May-July), (2021)pp. 612-626

Accredited SINTA SK.NOMOR 28/E/KPT/2019

Open Access at:http://ojs.uho.ac.id/index.php/PUBLICUHO/index

DOI: 10.35817/jpu.v4i2.18117

disamping sebagai abdi negara. Dalam konteks ini masyarakatlah sebagai aktor utama (pelaku) pembangunan, sedangkan pemerintah berkewajiban untuk mengarahkan, membimbing serta menciptakan suasana yang menunjang kegiatan-kegiatan dari masyarakat tersebut. Pada kondisi ini aparatur negara dituntut untuk lebih mampu memperbaiki kinerjanya (pelayanan prima) dan diharapkan lebih mampu merumuskan konsep atau menciptakan iklim yang kondusif, sehingga sumber daya pembangunan dapat menjadi pendorong percepatan terwujudnya masyarakat yang mandiri dan sejahtera. Pelayanan yang telah menunjuk kepada aturan formal dianggap telah memenuhi sendisendi pelayanan yang baik dan aparat pelayanan dianggap telah konsisten dalam menerapkan aturan hukum pelayanan. (Muhammad Elwan, 2019)

\section{Konsep Kualitas Pelayanan Publik}

Dalam Undang-Undang No. 25 Tahun 2009 tentang pelayanan publik, mendefinisikan bahwa pelayanan publik adalah kegiatan atau serangkaian kegiatan dalam rangka pemenuhan kebutuhan pelayanan sesuai dengan peraturan perundang-undangan bagi setiap warga negara dan penduduk atas barang, jasa dan atau pelayanan administratif yang disampaikan oleh penyelenggara dan pembuat pelayanan publik. Menurut Gotlieb et al. (1994) (dalam (Trivedi \& Jagani, 2018) Observed that patient satisfaction was a result of perceived service. (kepuasan pasien adalah hasil dari kualitas layanan yang dirasakan.) Sedangkan Menurut Giovanis et al., 2018 (dalam Zhang et al., 2020) Service quality is a means for achieving increased patronage, competitive advantage and long-term profitability. (kualitas layanan adalah cara untuk mencapai peningkatan perlindungan, keunggulan kompetitif, dan profitabilitas jangka panjang). Kualitas pelayanan publik menjadi sangat penting, karena terkait dengan kepuasan pihak yang dilayani (Yusuf \& Banga, 2019).

Jadi, disimpulkan bahwa kualitas pelayanan publik ialah seluruh alur kegiatan totalitas pelayanan yang dilaksanakan oleh penyelenggara ataupun pembuat pelayanan publik dalam rangka memenuhi kebutuhan dan harapan masyarakat yang sesuai dengan standar pelayanan yang telah diberlakukan. Pelayanan publik ini penting karena selalu berhubungan dengan kehidupan dalam masyarakat. Institusi yang bisa dikelompokkan ke dalam gugus pemeberi pelayanan publik adalah Institusi pemerintah dan non pemerintah (La Ode Aslim, 2018).

\section{METODOLOGI}

Jenis Penelitian kali ini adalah penilitian kualitatif deskriptif. Melalui metode kualitatif diharapkan hasil yang diperoleh mampu menyajikan data-data yang diperlukan untuk menjawab pertanyaan penelitian secara detil dan mendalam (Hidayat, 2020). Fokus penelitian sesuai dengan lima dimensi kualitas pelayanan yaitu: Tangibles, Reability, 
Responsiveness, Assurance, Empathy. Sumber data pada penelitian ini menggunakan data primer yang didapatkan melalui hasil wawancara dengan Bapak dr. C James Kalengkongan selaku Kepala UPTD Puskesmas Perawatan Baru Ulu Balikpapan. Sedangkan data sekunder yaitu data yang dibutuhkan untuk melengkapi data premier. Data ini diperoleh dari literatueliteratur. Dokumen-dokumen secara tidak langsung dari obyek penelitian, dalam hal ini, peneliti memanfaatkan data yang diperoleh dari Indek Kepuasan Masyarakat (IKM) pada tahun 2019 dan 2020. Data yang sudah dikumpulkan peneliti selanjutnya dilakukan analisis dan interpretasi data yaitu melalui reduksi data yakni data yang diperoleh dikelompokkan sesuai dengan kebutuhan, kemudian data yang sudah dikelompokkan disajikan dan pada akhirnya ditarik kesimpulan atas jawaban-jawaban yang diberikan informan dengan menggunakan wawancara, observasi, ataupun studi dokumentasi.

\section{HASIL DAN PEMBAHASAN}

\section{Tangibles (Ketampakan fisik)}

Dimensi ini berkaitan dengan usaha pemberian pelayanan yang terbaik oleh UPTD Puskesmas Perawatan Baru Ulu yang harus didukung oleh fasilitas baik fisik maupun non-fisik. Fasilitas fisik yang memadai, lengkap serta berkualitas akan membantu memberi kepuasan bagi pengguna layanan. Dimensi tangibles dalam upaya untuk mengetahui kualitas pelayanan di UPTD Puskesmas Perawatan Baru Ulu sudah cukup baik dan memadai dari segi kondisi Gedung dan kebersihannya. Hal ini dinyatakan oleh informan yaitu Bapak dr. C James Kalengkongan selaku Kepala Puskesmas UPTD Puskesmas Perawatan Baru Ulu, yang menyatakan saat wawancara bahwa "UPTD Puskesmas Perawatan Baru Ulu terbagi dua gedung tempat pelayanan. Satu rawat inap dan satu rawat jalan. Secara standart untuk pelayanan rawat jalan maupun rawat inap, tempat itu sudah sesuai dengan apa yang diperuntukkan pelayanan- pelayanan yang dimaksud jadi kalau misal di rawat jalan di polipoli maupun di tempat pemeriksaan laboratorium maupun tempat yang lain-lain untuk yang rawat inap ada tempat tidur untuk rawat inap dan rawat inap, seperti itulah kalau masalah tempat". Sedangkan untuk masalah kebersihan Bapak dr. C James Kalengkongan menjelaskan bahwa Masing-masing gedung mempunyai petugas kebersihan bernama cleaning servies.

Melalui wawancara yang dilakukan, menurut informan yaitu Bapak dr. C James Kalengkongan selaku Kepala Puskesmas UPTD Puskesmas Perawatan Baru Ulu, mengenai kondisi ruang tunggu beliau menyatakan,

"Ruang tunggu relative memadai, tidak terlalu besar tapi cukup untuk membuat pasien berobat menunggu di ruangan. Tapi kalau dia datang dalam jumlah yang sangat banyak pasti tidak mencukupi. Tapi secara standart, sudah sesuai."

Hasil observasi peneliti terkait kondisi ruang tunggu, toilet, dan sekitar Gedung UPTD Puskesmas Perawatan Baru Ulu sudah baik dan nyaman untuk digunakan oleh pengguna 


\section{Journal Publicuho}

ISSN2621-1351 (online), ISSN 2685-0729 (print)

Volume 4 Number 2 (May-July), (2021)pp. 612-626

Accredited SINTA SK.NOMOR 28/E/KPT/2019

Open Access at:http://ojs.uho.ac.id/index.php/PUBLICUHO/index DOI: 10.35817/jpu.v4i2.18117

layanan. Berdasarkan wawancara tersebut terlihat bahwa kondisi sarana prasarana di UPTD Puskesmas Perawatan Baru Ulu mengacu pada standar pelayanan yang sudah ditetapkan. Hal ini serupa dengan data Indeks Kepuasan Masyarakat yaitu masyarakat menilai cukup baik untuk poin kondisi sarana prasarana.

\section{Reability (Reabilitas)}

Pada dimensi ini berkaitan dengan kemampuan UPTD Puskesmas PerawatanBaru Ulu untuk memberikan layanan yang akurat sejak pertama kali tanpa membuat kesalahan apapun dan menyampaikan jasanya sesuai dengan waktu yang disepakati.

Menurut informan yaitu Bapak dr. C James Kalengkongan selaku Kepala Puskesmas UPTD Puskesmas Perawatan Baru Ulu, mengenai kesesuaian standart pelayanan beliau menyatakan, "Kita ini kan secara standar kita sudah terakreditasi yajadi pelayanannya memang sesuai standar walaupun mungkin ada hal-hal tertentu yang mungkin karena masalah keburu waktu dan sebagainya kasus kasusnya tapi pada prinsipnya itu sudah sesuai dengan standar yang berlaku untuk pelayanan yang diperlukan di puskesmas"

Selanjutnya beliau menyatakan mengenai kemudahan prosedur pelayanan yang dilakukan UPTD Puskesmas Perawatan Baru Ulu sebagai berikut:

"Jadi kalau kemudahannya kita sesuai standart selalu Kembali ke standar, jadi kalau sebenarnya dari untuk membicarakan itu kan kita perlu tau alurnya ya jadi dari pasien datang karena sekarang adalah dalam masa pandemi ya jadi dia harus cuci tangan ya pakai masker masuk baru dia ada tim screening di depan, tim screening untuk mengecek apa dia panas atau tidak dan sebagainya kemudian dikasi nomor antrian baru dia menunggu untuk dipanggil di loket nah dari loket itu setelah datang dia baru diarahkan ke poli mana poliklinik mana pergi untuk pemeriksaan apa kami arahkan dari loket jadi sesuai standar."

Selanjutnya beliau juga menyatakan mengenai ketepatan waktu pelayanan yang dilakukan UPTD Puskesmas Perawatan Baru Ulu sebagai berikut:

"Ketepatan waktu kita punya standart pelayanan juga sih untuk masalah waktu pelayanan baik di loket, maupun di poli-poli jadi apa namanya jadi kita ada misalnya untuk pertama kita untuk pasien mengambil antrian itu kan dia harus mengambil antrian kemudian harus menunggu dan petugas-petugasnya sudah siap di masing-masing tempat. Kalau sudah dianggap waktunya sudah pas untuk memulai siap untuk dipanggil satu-satu pasiennya sesuai nomor antrian"

Berdasarkan wawancara tersebut terlihat bahwa segala bentuk pelayanan dari UPTD Puskesmas Perawatan Baru Ulu mengacu pada standar pelayanan yang sudah ditetapkan. Hal ini serupa dengan data Indeks kepuasan masyarakat yaitu masyarakat menilai baik untuk poin penilaian kejelasan persyaratan untuk mendapat pelayanan, kemudahan prosedur/mekanisme/sistem pelayanan. Serta penilaian cukup baik untuk kesesuaian/ketepatan waktu pelayanan dengan standar pelayanan. Namun, pada Survey Kepuasan Masyarakat tersebut UPTD Puskesmas Perawatan Baru Ulu mendapatkan nilai 
terendah pada poin penilaian Ketepatan waktu kedatangan dokter. Yang berarti masyarakat sadar dan memperhatikan bahwa kedatangan dokter di Puskesmas mengalami keterlambatan.

\section{Responsiveness (Responsivitas)}

Pada dimensi ini berkenaan dengan kesediaan dan kemampuan para karyawan UPTD Puskesmas Perawatan Baru Ulu untuk membantu para pelanggan dan merespon permintaan mereka, serta menginformasikan kapan jasa akan diberikan dan kemudian memberikan jasa secara cepat.

Menurut informan yaitu Bapak dr. C James Kalengkongan selaku Kepala Puskesmas UPTD Puskesmas Perawatan Baru Ulu, mengenai respon Puskesmas dalam melayani dan merespon keluhan dari masyarakat adalah sebagai berikut :

"Jadi keluhan itu banyak macam cara masuk, bisa dia masuk dengan keluhan complain langsung bisa dengan mengirim di WA atau dia menulis kotak saran yang sudah tersedia. Jadi Kalau dia masuk kita akan membahasa itu dan apa yang di apa di komplainkan ke kita, kita konfirmasikan ke petugas yang terkait."

Selanjutnya beliau juga menyatakan mengenai keluhan yang masuk kepada UPTD Puskesmas Perawatan Baru Ulu pada tahun 2020 sebagai berikut:

"Ya, ada tapi kebanyakan keluhan kan keluhan-keluhan yang langsung pada saat itu misalnya mereka lama menunggu kemudian dibatasi pelayanannya, orangorangnya dibatasi tidak seperti tahun 2019 karena masa pandemi covid-19 ini kita membatasi jumlah pasien kemudian harus diperiksa dengan seksama jadi ya komplain seperti itu tapibiasa saja ada yang memang perlu cepat jadi mereka tidak sabar antri ya complain sepertiitu."

Berdasarkan wawancara tersebut terlihat bahwa para karyawan UPTD Puskesmas Perawatan Baru Ulu sudah menanggapi keluhan masyarakat dengan baik. Sama halnya dengan data Indeks Kepuasan Masyarakat, pada poin penilaian respon petugas pelayanan terhadap pengaduan yang disampaikan pengguna layanan mendapatkan nilai yang baik dari masyarakat.

\section{Assurance (Kepastian)}

Dimensi ini menekankan pada kemampuan UPTD Puskesmas Perawatan Baru Ulu Balikpapan untuk membangkitkan rasa percaya keyakinan diri pasien bahwa pihak Puskesmas terutama petugasnya mampu memenuhi kebutuhan pasiennya, serta memberikan pelayanan dengan kepastian dan bebas dari keragu-raguan, sehingga dapat terus menaruh kepercayaan kepada institusi publik tersebut.

Hasil wawancara peneliti dengan informan Bapak dr. C James Kalengkongan selaku Kepala Puskesmas UPTD Puskesmas Perawatan Baru Ulu memperjelas terkait cara memberikan jaminan kepercayaan kepada masyarakat. Dalam hal ini, beliau mengatakan bahwa :

"lya jadi ada banyak ada beberapa metode pertama kita melakukan penyuluhan , penyuluhan baik di dalam Gedung, penyuluhan sementara pasien menunggu ada 


\section{Journal Publicuho}

ISSN2621-1351 (online), ISSN 2685-0729 (print)

penyuluhan-penyuluhan terkait dengan pelayanan kita kemudian kita bisa penyuluhan di dalam RT-RT di posyandu atau di pertemuan-pertemuan apa saja yang melibatkan tokoh-tokoh masyarakat supaya mereka memahami apa yang terjadi mekanisme di puskesmas jadi jangan karena mau buru-buru maunya lebih duluan padahal dia datangnya belakangan banyak kali yang begitu yang tidak sabar akhirnya ribut kenapa saya belum dilayani padahal ada antrian sebelumnya ya seperti itu kemudian lewat media sosial lewat WA, lewat Instagram lewat facebook, lewat apa saja yang bisa menyampaikan kepada masyarakat untuk berobat di puskesmas dengan keluhan-keluhan yang ada seperi itu"

Berdasarkan pada data diatas, menunjukkan bahwa Puskesmas Perawatan Baru Ulu Balikpapan telah memberikan jaminan kepercayaan kepada masyarakat sekitar untuk berobat dan memeriksakan kesehatan mereka di Puskesmas. Selain itu, para petugas juga memberikan kepercayaan dengan cara penyuluhan ataupun pertemuan terkait dengan pelayanan yang diberikan oleh puskesmas dan juga terkait mekanisme pelayanannya khususnya dalam hal antrian sehingga dapat menghindari terjadinya keributan sesama pasien. Sama halnya dengan data Indeks Kepuasan Masyarakat UPTD Puskesmas Perawatan Baru Ulu Balikpapan pada poin system antrian yang disediakan mendapatkan nilai tertinggi dari nilai rata-rata unsur pelayanan.

\section{Emphaty (Perlakuan)}

Pada dimensi ini, kemampuan UPTD Puskesmas Perawatan Baru Ulu Balikpapan dalam memberikan perhatian yang tulus dan bersifat individual yang diberikan kepada pasien dengan berupaya memahami keinginannya dalam memberikan pelayanan. Empati menyangkut pemberian pelayanan yang baik kepada pasien dalam hal ini keramahan, sopan santun, dan kesabaran dalam memberikan pelayanan serta keadilan kepada pasien tanpa membeda-bedakan status sosial.

Hasil wawancara peneliti dengan informan Bapak dr. C James Kalengkongan selaku Kepala Puskesmas UPTD Puskesmas Perawatan Baru Ulu memperjelas terkait keadilan dalam hal memberikan pelayanan kepada pasien. Beliau mengatakan bahwa :

"lya jadi untuk masalah keadilan itu relative tapi prinsip keadilan disini kita tidak membedakan dia rakyat biasa dia BPJS dia bukan BPJS dia pasien umum dia pejabat semua sama kalau harus antri ya antri itu adil kemudian dilayani oleh dokter yang sama, oleh perawat yang sama, bidan yang sama itu siapa saja sesuai dengan jadwal tugas dari masing-masing pegawai"

Lalu peneliti menanyakan mengenai ketepatan waktu pelayananan puskesmas, dan beliau menjelaskan bahwa:

"Ketepatan waktu kita punya standart pelayanan juga sih untuk masalah waktu pelayanan baik di loket, maupun di poli-poli jadi apa namanya jadi kita ada misalnya untuk pertamakita untuk pasien mengambil antrian itu kan dia harus mengambil antrian kemudian harus menunggu dan petugas-petugasnya sudah siap di masing-masing tempat. Kalau sudah dianggap waktunya sudah pas untuk memulai siap untuk dipanggil satu-satu pasiennya sesuai nomor antrian." 
Selain itu, peneliti juga menanyakan tentang sikap petugas dalam memberikan pengertian atas keluhan-keluhan yang berasal dari pasien, beliau mengatakan bahwa :

"Kalau sikap petugas medis itu pokoknya selalu kita kembali ke standar jadi kalau misalnya sudah sesuai dengan standar nah mereka melakukan pelayanan yang terbaik. Jadi, Pelayanan terbaik itu mungkin dari masing-masing orang berbeda dari pasien atau pelanggan untuk meresponnya. Nah kalau misalnya dari petugas sudah melakukan pelayanan terbaik dan dari pasien ada komplain secara administrasi atau pelayanannya maka kita akan langsung membicarakan apa yang dikomplain secara diskusi kemudian kalau ada hal-hal yang perlu ditindaklanjuti dalam bentuk administrasi tergantung sepertiapa kalau misalnya dari hasil diskusi ternyata ada kelalaian kita akan memberikan surat teguran melalui surat berkali-kali. Kalau misalnya tidak ya berarti kita harus mengklarifikasi ke pasien yang bersangkutan maksudnya apa komplainnya seperti itu check and recheck namanya."

Berdasarkan data diatas menunjukkan bahwa petugas Puskesmas Perawatan Baru Ulu Balikpapan telah menunjukkan dan memberikan pelayanan terbaik mereka terkait sikap empatinya sesuai dengan standar pelayanan yang telah ditetapkan, dalam hal ini mengenai ketepatan waktu pelayanan petugas kepada pasien serta merespons atas keluhan pasien dengan cara check dan recheck. Selain itu, para petugas juga tidak membeda-bedakan status sosial pasien, dan melayani pasien sesuai dengan jadwal serta antrian kedatangan.

\section{KESIMPULAN}

Berdasarkan hasil dan pembahasan pada bab sebelumnya, maka dapat disimpulkan sebagai berikut:

1. Kualitas UPTD Puskesmas Perawatan Baru Ulu dalam dimensi Tangible yaitu sudah cukup baik untuk sarana dan prasarana dan sesuai dengan standar pelayanan.

2. Kualitas UPTD Puskesmas Perawatan Baru Ulu dalam dimensi Reability yaitumemberikan pelayanan yang akurat sesuai dengan standar yang telah ditetapkan. Namun, menurut masyarakat ketepatan waktu kedatangan dokter kurang.

3. Kualitas UPTD Puskesmas Perawatan Baru Ulu dalam dimensi Responsiveness yaitu petugas sudah memberikan layanan pemberian keluhan dari masyarakat melalui berbagai cara serta, menanganinya dengan tanggap.

4. Kualitas UPTD Puskesmas Perawatan Baru Ulu dalam dimensi Assurance yaitu petugas sudah sangat baik dalam mengatur sistem antrian dan jadwal pasien.

5. Kualitas UPTD Puskesmas Perawatan Baru Ulu dalam dimensi Emphaty yaitu etika dan perilaku petugas kurang baik dalam hal memberikan pelayanan.

6. Secara keseluruhan hasil penelitian ini menunjukkan bahwa kualitas pelayanan yang diberikan oleh UPTD Puskesmas Perawatan Baru Ulu Kota Balikpapan telah memberikan kualitas pelayanan yang cukup baik sehingga implikasi terhadap kualitas pelayanan menghasilkan kurangnya kepuasan dari masyarakat. 


\section{Journal Publicuho}

ISSN2621-1351 (online), ISSN 2685-0729 (print)

\section{SARAN}

Saran bagi UPTD Puskesmas Perawatan Baru Ulu berdasarkan kesimpulan di atas dalam hal ketepatan waktu kedatangan dokter perlu lebih diperhatikan kembali serta diperbaiki agar pelayanan kepada masyarakat bisa lebih maksimal. Agar pasien merasa puas dalam pelayanan yang diberikan. Selanjutnya, dalam hal etika perilaku petugas juga harus lebih diperhatikan kembali, di saat ada laporan harus segera diperbaiki sehingga tidak ada lagi terjadi kesalahan-kesalahan yang sama di waktu-waktu selanjutnya.

\section{REFERENSI}

Abdussamad, J. (2019). Kualitas Pelayanan Publik Di Kantor Dinas Kependudukan Dan Catatan Sipil Kabupaten Gorontalo. Publik: Jurnal Manajemen Sumber Daya Manusia, Administrasi Dan Pelayanan Publik, 6(2), 73-82. https://doi.org/10.37606/publik.v6i2.6

Azhar, B. (2018). Analisis Kualitas Pelayanan Publik dalam Memberikan Kepuasan kepada Masyarakat pada Puskesmas Lempake Kota Samarinda. ADMINISTRASI PUBLIK, 1(1). https://garuda.ristekbrin.go.id/documents/detail/975207

Campos, D. F., Bezerra, R., Filho, N., \& Castro, F. N. (2016). International Journal of Health Care Quality Assurance For Authors SERVICE QUALITY IN PUBLIC HEALTHCLINICS: PERCEPTIONS OF USERS AND HEALTH PROFESSIONALS. International Journal of Healt Care Quality Assuraance. https://doi.org/10.1 108/IJHCQA-09-2016-0140

Daton, D. B. (2020). Layanan Publik dan Kepuasan Masyarakat. https://ombudsman.go.id/artikel/r/artikel--layanan-publik-dan-kepuasanmasyarakat

Dewi Maharani. (2019). Pengaruh Manajemen Sumber Daya Manusia dan Budaya Organisasi Terhadap Kualitas Kinerja Pegawai Pada Kantor Kecamatan Cikijing Kabupaten Majalengka. Dinamika Governance: Jurnal Ilmu Administrasi Negara, 9(2), 101-110.

Didin Fatihudin \& Anang Firmansyah. (2019). Pemasaran Jasa (Strategi, Mengukur Kepuasan dan Loyalitas Pelanggan). CV Budi Utama.

Endeshaw, B. (2020). Healthcare service quality-measurement models: a review. Journal of Health Research, 35(2), 106-117. https://doi.org/10.1 108/JHR-07-2019-0152

Gajewska, T., Zimon, D., Kaczor, G., \& Madzík, P. (2019). The impact of the level of customer satisfaction on the quality of e-commerce services. International Journal of Productivity and Performance Management, 69(4), 666-684. https://doi.org/10.1108/IJPPM-01-2019-0018

Gómez-Cruz, M. E. (2019). Electronic reference services: a quality and satisfaction evaluation. Reference Services Review, 47(2), 118-133. https://doi.org/10.1108/RSR07-2018-0057 
Hernikawati, D. (2018). Indeks Kepuasan Masyarakat Terhadap Layanan Komunikasi Data Di Pjkkd Batan. Jurnal Studi Komunikasi Dan Media, 22(1), 29. https://doi.org/10.31445/jskm.2018.220103

Hidayat, E. (2020). ANALISIS SUMBER DAYA DALAM PROGRAM PERNIKAHAN GRATIS DI KANTOR URUSAN AGAMA KECAMATAN PAKAL KOTA SURABAYA. PUBLIC ADMINISTRATION JOURNAL OF RESEARCH, 2(4), 416-430.

La Ode Aslim. (2018). Pengaruh Kualitas Pelayanan Terhadap Peningkatan Penerimaan Retribusi Daerah. Journal Publicuho, 1 (1), 45. https://doi.org/http://dx.doi.org/10.35817/jpu.v1i1.6293

John Fresly Hutahaen, A Yuli Andi Gani, Choirul Saleh, S. S. (2018). The factors affecting the implementation of freedom of information policy and public service performance (A case study at Jakarta Capital City Government). International Journal of Law and Management, 10(24), 3 .

Khozin, M., \& Mutmainah, N. F. (2019). Kualitas Pelayanan Kesehatan Lansia di Kota Yogyakarta (Studi kasus pelayanan kesehatan pada Puskesmas Mantrijeron). Jurnal Manajemen Pelayanan Publik, 1 (2), 143. https://doi.org/10.24198/jmpp.v1i2.18452

Krismanto, H., \& Irianto, S. (2020). Analisis Kualitas Pelayanan Rawat Jalan Pada Rumah Sakit Umum Daerah (Rsud) Kota Dumai. Jurnal Manajemen Pelayanan Publik, 3(1),32. https://doi.org/10.24198/jmpp.v3i1.26677

Kuye, O. L., \& Akinwale, O. E. (2020). Conundrum of bureaucratic processes and healthcare service delivery in government hospitals in Nigeria. Journal of Humanities and Applied Social Sciences, 3(1), 25-48. https://doi.org/10.1 108/jhass-12-2019-0081-

LUkman Arif. (2019). KUALITAS PELAYANAN BALAI PEMBERANTASAN DAN PENCEGAHAN PENYAKIT PARU DI PAMEKASAN. Dinamika Governance: Jurnal Ilmu Administrasi Negara, 9(1), 78-90.

Muis, A. (2017). Analisis Kualitas Pelayanan Kesehatan di Puskesmas Kecamatan Kongbeng Kabupaten Kutai Timur. ADMINISTRASI PUBLIK, 1 (1). https://garuda.ristekbrin.go.id/documents/detail/763954

Muhammad Elwan, La Ode. "Problem Birokrasi dalam Meningkatan Pelayanan Publik pada Sekretariat Daerah Kabupaten Muna." Journal Publicuho, vol. 2, no. 2, 2019, pp. 31-42, doi:10.35817/jpu.v2i2.7223.

Nawangsari, E. R., Purwanto, E., \& Hariyawati, S. (2016). ANALISIS KUALITAS PELAYANAN ADMINISTRASI KECAMATAN DI KABUPATEN SIDOARJO. Dinamika Governance: Jurnal Ilmu Administrasi Negara, 6 (1), 43-54.

Peraturan Menteri Kesehatan Republik Indonesia Nomor 75 Tahun 2014 Tentang Pusat Kesehatan Masyarakat. (n.d.).

Pratama, D. P., \& Widiyarta, A. (2016). Kualitas PERUM DAMRI Pemerintah Kota Surabaya (Study Kasus Transportasi Pada Bus Trans Sidoarjo). Dinamika Governance: Jurnal IImu Administrasi Negara, 6(2), 182-190.

Pustaka, B. (1990). Kamus Besar Bahasa Indonesia. Balai Pustaka.

Rahman, M. K. (2019). Medical tourism: tourists' perceived services and satisfaction lessons from Malaysian hospitals. Tourism Review, 74 (3), 739-758. https://doi.org/10.1 108/TR01-2018-0006

Rezha, F. (2013). Analisis Pengaruh Kualitas Pelayanan Publik Terhadap Kepuasan Masyarakat (Studi Tentang Pelayanan Perekaman Kartu Tanda Penduduk Elektronik 


\section{Journal Publicuho}

ISSN2621-1351 (online), ISSN 2685-0729 (print)

(E-KTP) Di Kota Depok). Jurnal Administrasi Publik Mahasiswa Universitas Brawijaya, 1 (5), 981-990.

Risnawan, W. (2017). Fungsi Birokrasi dalam Efektivitas Pelayanan Publik. Dinamika: Jurnal IImiah Ilmu Administrasi Negara, 4(1).

Rosyadi, F. (2017). Kualitas Pelayanan Badan Penyelenggara Jaminan Sosial (Bpjs) Kesehatan Di Puskesmas Wonoayu Kabupaten Sidoarjo. JPAP: Jurnal Penelitian Administrasi Publik, 3(1), 690-693. https://doi.org/10.30996/jpap.vi1.1240

Septiana., N. W. (2016). KUALITAS PELAYANAN KESEHATAN3 DI PUSKESMAS ROWOSARI KECAMATAN TEMBALANG KOTA SEMARANG. Journal of Public Policy and Management Review, 5(3), 1689-1699.

Shabbir, A., Malik, S. A., \& Janjua, S. Y. (2017). Equating the expected and perceived service quality: A comparison between public and private healthcare service providers. In International Journal of Quality and Reliability Management (Vol. 34, Issue 8). https://doi.org/10.1108/IJQRM-04-2016-0051

Shobirin. (2016). HUBUNGAN PENERAPAN MANAJEMEN PUSKESMAS DAN KOMITMENKERJA PETUGAS DENGAN MUTU PELAYANAN PENGOBATAN DI POLI UMUM PUSKESMAS KABUPATEN BANGKALAN (Studi di Puskesmas Se-Kabupaten Bangkalan). JPAP: Jurnal Penelitian Administrasi Publik, 2 (02), 513-526. https://doi.org/10.30996/jpap.v2i02.1006

Sunardi, D. S. (2017). Kualitas Pelayanan Publik di Puskesmas Peneleh Kota Surabaya. JPAP: Jurnal Penelitian Administrasi Publik, 3(2), 823-831. https://doi.org/10.30996/jpap.v3i2.1263

Tarawiyah, S. (2017). Studi Tentang Kualitas Pelayanan Kesehatan Pada Kantor UPT Puskesmas Muara Wahu I Kabupaten Kutai Timur. ADMINISTRASI PUBLIK, 1 (1).

Trivedi, R., \& Jagani, K. (2018). Perceived service quality, repeat use of healthcare services and inpatient satisfaction in emerging economy: Empirical evidences from India. International Journal of Pharmaceutical and Healthcare Marketing, 12 (3), 288-306. https://doi.org/10.1 108/IJPHM-11-2017-0065

Umardiono, A., Andriati, A., \& Haryono, N. (2019). Peningkatan Pelayanan Kesehatan Puskesmas Untuk Penanggulangan Penyakit Tropis Demam Berdarah Dengue. JAKPP (Jurnal Analisis Kebijakan \& Pelayanan Publik), 60-67. https://doi.org/10.31947/jakpp.v4i1.5905

Undang-Undang Nomor 25 Tahun 2009 Tentang Pelayanan Publik

Upadhyai, R., Upadhyai, N., Jain, A. K., Roy, H., \& Pant, V. (2020). Health care service quality: a journey so far. Benchmarking, 27(6), 1893-1927. https://doi.org/10.1108/BIJ-03-2019$\underline{0140}$

Utami, I. A., \& Nawangsari, E. R. (2016). PERAN PUSKESMAS MEDOKAN AYU KOTA SURABAYA DALAM PENGENDALIAN PENYAKIT DEMAM BERDARAH DENGUE (DBD). Dinamika Governance: Jurnal Ilmu Administrasi Negara, 6(2), 127-138.

Valadi-khorram, S., Amiri, M. R., \& Saberi, M. K. (2020). Evaluating the quality of health information services in public libraries: an experience from Iran. Library Management, 42(3), 197-213. https://doi.org/10.1108/LM-01-2020-0001

Verma, P., Kumar, S., \& Sharma, S. K. (2020). e-Healthcare service quality: consumer satisfaction and its association with demographic characteristics. International 
ISSN2621-1351 (online), ISSN 2685-0729 (print

Volume 4 Number 2 (May-July-2021) pp.612-626

Endik Hidayat, et.al

DOI: $10.35817 / j p u . v 4 i 2.18117$

Journal of Health Care Quality Assurance, 33(6), 413-428. https://doi.org/10.1108/IJHCQA-02-2020-0030

Yusuf, M., \& Banga, W. (2019). IDENTIFIKASI KEMAMPUAN KERJA APARAT DAN PENGARUHNYA TERHADAP KUALITAS PELAYANAN PUBLIK (Studi Kasus di Kecamatan Abeli Kota Kendari). Journal Publicuho, 2(1), 38. https://doi.org/10.35817/jpu.v2i1.5990

Zhang, M., Wang, L., Wang, R., \& Xiong, J. (2020). Measuring hospital process service quality: emerging technologies' challenge. International Journal of Quality and Service Sciences, 12 (3), 319-336. https://doi.org/10.1108/IJQSS-02-20 